\title{
Dairy Products Consumption Attributes of Consumers: A Survey Study in Adana and Mersin Provinces
}

\begin{abstract}
This research aims to determine consumption attitudes and preferences of dairy products and effect of main demographic factors of the consumers living in Adana and Mersin provinces which were located in the south-east part of Turkey. In this context, a face-to-face survey was conducted with 518 people in Adana and Mersin provinces and 505 of these individuals were determined as milk and dairy products consumers. Since the obtained data did not show normal distribution ( $\mathrm{p}<0.01$ ), nonparametric tests were used to analyse the data. The results of the research show that there is a consumption concentration on some dairy products and 35-44 age group is the most dairy products consumed group among all. Income levels also effects the consumption and the supermarkets are the most preferred place for purchasing dairy products.
\end{abstract}

Key Words: Consumer Preferences, Dairy Products, Purchase Behaviour, Consumption.

\section{O. İnanç GÜNEY ${ }^{1}$}

Levent SANGÜN ${ }^{1}$

Suat DIKEL ${ }^{2}$

${ }^{1}$ Vocational School of Adana, University of Çukurova, Turkey.

${ }^{2}$ Faculty of Fisheries, University of Çukurova, Turkey

\section{Correspondence}

O. İnanç GÜNEY

inancguney@gmail.com

Article Info

Received: 12-10-2017

Accepted: 17-12-2017

Copyright ${ }^{\circledR} 2017$ JAVST 


\section{Introduction}

Consumer behaviour discipline is frequently used in food consumption studies to examine the common behaviours and choice patterns of different demographic groups on decision-making process (Rugimbana, 2007). Consumer behaviour refers to all the thought, feelings and actions that an individual has or takes before or while buying any product, service or idea. Buyer behaviour is the concept which answers what, why, how, when, and where an individual makes purchase. As a result, the outcome of buyer behaviour is the buyer's decision (Khaniwale, 2015).

Kotler and Armstrong (2004) specified classification consisted of four factors influencing consumer behaviour, namely cultural factors (i.e. culture, subculture and social class), social factors (i.e. member groups, reference groups, family, role and status), personal factors (i.e. age, family life cycle, occupation, economic situation, lifestyle, personality and selfconcept) and psychological factors (i.e. motivation, perception, learning, attitudes and beliefs) (Kurajdova and Petrovicova, 2015). Consumers' food consumption and purchasing behaviour is also affected and changed by a number of factors (Kızıloğlu and Kızılaslan, 2014).

Today, the adoption and success of developed marketing strategies, marketing mix and other marketing programs strongly depends on the company's ability of understanding consumer's needs and expectations. Consequently, studying, understanding and knowing consumers and their behaviour should belong to major and most important tasks of marketers (Kurajdova and Petrovicova, 2015).

To analyse the consumer behaviour and the attributes of the individuals specific methods could be used. One of the most used methods in marketing research is to classify consumer groups according to various common characteristics such as demographic variables. Among the demographic variables, the most common ones are gender, age, education, occupation, income, household size (Kızıloğlu and Kızılaslan, 2014; Şeker et al., 2012). Milk and dairy products are one of the most demanded food products due to the fact that they have many nutrients that are needed throughout individuals lives, and their consumption takes place in almost every period of the human life. Thus, they have a relatively high purchase frequency. The consumption level of dairy products can be regarded as a development indicator because of the high consumption of milk and dairy products in developed countries. (Onurlubaş and Çakırlar, 2016).

Growth in the world economy and population with increasing awareness of consumer have affected the consumption of milk and dairy products positively. Due to this situation prices and also the production of dairy products has increased (Terin, 2014). Similar structure has also experienced in Turkey and milk and dairy products produced in modern facilities are increasing day by day. Nevertheless, Turkey still lags behind developed countries in case of the production and consumption of dairy products (Gülaç, 2015; Onurlubaş and Çakırlar, 2016; Terin et al., 2015).

This research aims to determine consumption attitudes and preferences of dairy products of the consumers living in Adana and Mersin provinces which are located in the south-east part of Turkey. In this context, the demographic structures of the consumers are also taken into account for the analyses. It is expected that the results of the survey will contribute to milk and dairy sector representatives, decision makers and researchers. 


\begin{tabular}{lr}
$\begin{array}{l}\text { Tablo 1. Milk and dairy consumption in Turkey } \\
\text { (tons) (2015) }\end{array}$ \\
\hline \\
\hline Butter & 74.166 \\
Ayran & 597.000 \\
Cheese & 670.224 \\
Yoghurt & 1.133 .943 \\
Drinking milk & 1.322 .984 \\
Total & 3.798 .317 \\
\hline
\end{tabular}

TEPEGE, 2015

\section{Tablo 2. Milk and dairy production in Turkey (tons)} (2015)

\begin{tabular}{lr}
\hline Butter & 57.609 \\
Cheese & 660.976 \\
Ayran & 684.527 \\
Yoghurt & 1.173 .577 \\
Drinking milk & 1.444 .979 \\
Cow milk & 9.213 .188 \\
Other & 172.959 \\
Total & 4.194 .627 \\
\hline
\end{tabular}

TEPEGE, 2015

\section{Materials and Method}

The main material of the study is the face-to-face consumer survey. The survey was conducted on MayJune 2016 near by the supermarkets in the center of Adana and Mersin provinces where consumers are concentrated on purchasing behavior more. In the questionnaire, different socio-economic and demographic structures were taken into consideration and thus the attempt to increase the representation ability of the questionnaire was tried. The sample size of the study was calculated by using the formula given below. $n=\frac{p \cdot(1-p)}{(\mathrm{e} / \mathrm{Z})^{2}}$

In this formula, $\mathrm{n}$ is the sample volume, $\mathrm{p}$ is the frequency of the observed event, $\mathrm{e}$ is the error ratio, and $\mathrm{z}$ is the confidence interval. Based on the highest value of $\mathrm{p}(1-\mathrm{p})$, the error margin $\mathrm{e}=5 \%$ and the confidence interval $95 \%$ the sample size was assumed to as 518 people and 505 individuals were determined as consuming milk and milk products.

In the scope of the research before the data analyze, it was examined whether the data show normal distribution or not to decide the analyze method to be used. In this context, because the sample size is more than 50 Kolmogorov-Smirnov tests was applied and it was understood that the data did not show normal distribution because $\mathrm{p}<0.01$ (Table 3). For the reason that the data did not show normal distribution, nonparametric tests, Mann-Whitney $\mathrm{U}$ and Kruskalvalis, were applied. All the data were analysed into the SPSS 21 programme.

\section{Tablo 3. Tests of normality}

\begin{tabular}{lccc}
\hline \multicolumn{4}{c}{ Kolmogorov-Smirnov $^{\mathrm{a}}$} \\
& Statistic & $\mathrm{df}$ & Sig. \\
\hline $\begin{array}{l}\text { Dairy } \\
\text { products }\end{array}$ &, 126 & 518 &, 000 \\
\hline
\end{tabular}

\section{Results}

Depending on the data obtained from the survey study, primarily effects of demographic factors (gender, age, education and occupation) on dairy products consumption was investigated. The results of the analyses were given in Table 4. 
Tablo 4. Dairy products consumption according to demographic factors

\begin{tabular}{|c|c|c|c|c|c|}
\hline Education & Mean & $\mathrm{N}$ & Std. Deviation & Mean Rank & Chi-Square \\
\hline Literate & 3,0714 & 14 & ,49806 & 340,07 & \\
\hline Elementary-Middle School & 2,8373 & 295 & ,31302 & 246,32 & \\
\hline High school & 2,9021 & 160 & ,29918 & 274,66 & 8,284 \\
\hline University & 2,8865 & 46 & ,31644 & 264,76 & \\
\hline Graduate & 2,9259 & 3 & ,33945 & 290,00 & \\
\hline Total & 2,8685 & 518 & ,31735 & & \\
\hline Occupation & Mean & $\mathrm{N}$ & Std. Deviation & Mean Rank & Chi-Square \\
\hline Worker & 2,9201 & 32 & ,35725 & 288,80 & \\
\hline Officer & 2,8164 & 23 & ,32065 & 229,33 & \\
\hline Artisans and Craftsman & 2,7842 & 52 & ,30122 & 224,40 & \\
\hline Self-employment & 2,8904 & 152 & ,31087 & 268,07 & \\
\hline Private sector & 2,9148 & 30 &, 25217 & 289,08 & \\
\hline Student & 2,8321 & 45 & ,28586 & 238,47 & 7,975 \\
\hline Housewife & 2,8767 & 155 & ,34365 & 263,09 & \\
\hline Unemployed & 2,8000 & 10 & ,26605 & 238,75 & \\
\hline Retired & 2,8830 & 19 & ,29739 & 258,87 & \\
\hline Total & 2,8685 & 518 & ,31735 & 288,80 & \\
\hline Income & Mean & $\mathrm{N}$ & Std. Deviation & Mean Rank & Chi-Square \\
\hline No income & 2,7083 & 8 & ,20520 & 172,06 & \\
\hline $1000<$ & 2,8266 & 66 & ,37497 & 240,55 & \\
\hline 1000-1999 & 2,8699 & 281 & ,31186 & 261,48 & \\
\hline 2000-2999 & 2,8557 & 107 & ,28806 & 251,36 & 9,367 \\
\hline 3000-3999 & 2,9350 & 41 & 29395 & 287,95 & \\
\hline $4000>$ & 3,0222 & 15 & ,40325 & 332,80 & \\
\hline Total & 2,8685 & 518 & ,31735 & & \\
\hline Age & Mean & $\mathrm{N}$ & Std. Deviation & Mean Rank & Chi-Square \\
\hline $24<$ & 2,7981 & 82 & ,29274 & 222,18 & \\
\hline $25-34$ & 2,8802 & 102 & ,29322 & 263,00 & \\
\hline $35-44$ & 2,9189 & 126 & ,31597 & 288,57 & $11,004 *$ \\
\hline $45-54$ & 2,8487 & 141 & ,32101 & 248,73 & \\
\hline $54>$ & 2,8839 & 67 & ,36363 & 267,86 & \\
\hline Total & 2,8685 & 518 &, 31735 & & \\
\hline
\end{tabular}




\begin{tabular}{llllll}
\hline Gender & Mean & $\mathrm{N}$ & Std. Deviation & Mean Rank & $\begin{array}{l}\text { Mann- } \\
\text { Whitney U }\end{array}$ \\
\hline Male & & & & & \\
Female & 2,8284 & 279 &, 29587 & 241,14 & \\
& 2,9154 & 239 &, 33530 & 280,93 & 28218,000 \\
Total & & & & & $(-3,038)^{* *}$ \\
\hline
\end{tabular}

$*: \mathrm{p}<0,05 ; * *: \mathrm{p}<0,01$

The results show that, while gender and age factors differences are significant and effecting the dairy products consumption, differences on other demographic factors (education, occupation, income) has no significant effect on dairy products consumption. For the gender factor, it was determined that female individuals consume more dairy products than male individuals. Besides the age group 35-44 has the most consumption situation among age groups. For all the demographic factors, the consumption is over the average.

Dairy products consumption behavior of the individuals was also investigated by the scope of the research. The results are given in Table 5 .

\section{Tablo 5. Dairy products preferences}

\begin{tabular}{lllllllllll}
\hline & \multicolumn{2}{c}{ Never } & \multicolumn{2}{c}{ Rarely } & \multicolumn{2}{c}{ Sometimes } & \multicolumn{2}{c}{ Always } & \multicolumn{3}{c}{ Total } \\
& $\mathrm{f}$ & $\%$ & $\mathrm{f}$ & $\%$ & $\mathrm{f}$ & $\%$ & $\mathrm{f}$ & $\%$ & $\mathrm{f}$ & $\%$ \\
\hline Sheep Yogurt & 467 & 90,2 & 19 & 3,7 & 17 & 3,3 & 15 & 2,8 & 518 & 100 \\
Cow Yogurt & 10 & 1,9 & 6 & 1,2 & 26 & 5 & 476 & 91,9 & 518 & 100 \\
Cow Cheese & 63 & 12,2 & 60 & 12,6 & 80 & 15,4 & 315 & 60,1 & 518 & 100 \\
Sheep Cheese & 422 & 81,5 & 30 & 5,8 & 34 & 6,6 & 32 & 6,1 & 518 & 100 \\
Goat Cheese & 209 & 40,3 & 20 & 3,9 & 72 & 13,9 & 217 & 41,9 & 518 & 100 \\
Ayran & 1 & 0,2 & 3 & 0,6 & 16 & 3,1 & 498 & 96,1 & 518 & 100 \\
Ice ceram & 8 & 1,5 & 49 & 9,5 & 303 & 58,5 & 158 & 30,5 & 518 & 100 \\
Butter & 2 & 0,4 & 31 & 6,0 & 213 & 41,1 & 272 & 52,5 & 518 & 100 \\
Milk cream & 29 & 5,6 & 114 & 22 & 217 & 41,9 & 158 & 30,5 & 518 & 100 \\
\hline
\end{tabular}

Table 5 shows the preference structure of consumers against basic dairy products. Almost all consumers consume cow yoghurt (92\%), but they have the exact opposite attitude to consumption of sheep yoghurt. The same consumption structure is also valid for sheep cheese and it has been determined that they prefer goat cheese besides cow cheese for cheese consumption.
However, there is a different attitude about goat cheese consumption and consumers generally responded as never consuming (40.3) or always consuming (41.9). There is also a high preference for the consumption of Ayran, which is a traditional Turkish drink. Seasonal effect is observed in ice cream consumption, but there is almost no consumption. For butter consumption status, 
consumers have a very high consumption level and

butter(\%52,5).

almost all consumers have stated that they consume

Tablo 6. Dairy products purchase preference structure

\begin{tabular}{lcccccccccc}
\hline & \multicolumn{2}{c}{ Never } & \multicolumn{2}{c}{ Rarely } & \multicolumn{2}{c}{ Sometimes } & \multicolumn{2}{c}{ Always } & \multicolumn{3}{c}{ Total } \\
\hline & $\mathrm{f}$ & $\%$ & $\mathrm{f}$ & $\%$ & $\mathrm{f}$ & $\%$ & $\mathrm{f}$ & $\%$ & $\mathrm{f}$ & $\%$ \\
\hline Local market & 450 & 86,9 & 33 & 6,4 & 25 & 4,8 & 10 & 1,9 & 518 & 100 \\
Neighborhood & 310 & 59,8 & 112 & 21,6 & 70 & 13,6 & 26 & 5,0 & 518 & 100 \\
stores & & & & & & & & & & \\
Supermarket & 102 & 19,7 & 27 & 5,2 & 139 & 26,8 & 250 & 48,3 & 518 & 100 \\
Dairy & 333 & 64,3 & 15 & 2,9 & 83 & 16,0 & 87 & 16,8 & 518 & 100 \\
Delicatessen & 336 & 64,9 & 32 & 6,2 & 104 & 20,1 & 46 & 8,8 & 518 & 100 \\
Internet & 517 & 99,8 & 1 & 0,2 & - & - & - & - & 518 & 100 \\
\hline
\end{tabular}

Table 6 shows where the purchase of dairy products is made. Accordingly, consumers generally purchase dairy products from supermarkets. They also buy dairy products from dairies. Neighborhood grocery stores and local markets are places where purchases are made at very low levels and consumers do not use the internet environment to purchase dairy products.

\section{Discussion and Conclusions}

As in other food products, socio-economic and demographic structures of consumers also influence consumption preferences in consumption of dairy products. Studies that examine the relationship between consumption of milk and milk products and socioeconomic conditions show that factors such as gender, income level, education level, age, family size influence milk consumption in milk consumption (Onurlubaş and Çakırlar, 2016).

In food marketing, where milk and dairy products are included, consumers' purchasing behavior, consumption preferences and awareness levels contribute to the decision making and planning of the suppliers, producers and policy makers in the sector, and therefore it is important to conduct research on the subject (Kızıloğlu and Kızılaslan, 2014).

The results of the study show that demographic factors, gender and age differences have an impact on dairy consumption, but differences in other demographic factors (income, education, occupation) have no significant effect on consumption. In this context, it is understood that women are more willing to consume dairy products than men. It has also been determined that the 35-44 age group has the highest consumption of dairy products.

Among the dairy products, the most preferred products are ayran and cow-yogurt, and almost all of the consumers consume these products. Consumption preferences are also high for cow cheese and butter, and consumers often prefer these products. In addition to cow's milk products, goat cheese also has an important consumption structure in the field of research, but there is a dual structure in consumption of goat cheese. Almost half of the consumers stated that they always 
consume this product $(41.9 \%)$ while the other half stated that they never consumed it $(40,3)$.

In the case of ice cream consumption, there is a scattered consumption structure due to seasonality and there is almost no person who does not consume. Consumers show a very low demand for sheep milk products such as sheep cheese and sheep yogurt. The prices of these products are higher than those of cow milk products and the consumption habits are influential in this.

Within the scope of the research, it was also examined where consumers buy dairy products and most of them

\section{References}

Gülaç, N.Z., (2015). Süt ve Süt Ürünleri Durumu Tahmin, TEPEGE, No: 256.

Khaniwale, M. (2015). Consumer Buying Behavior, International Journal of Innovation and Scientific Research, 14(2), 278-276.

Kızıloğlu, R., \& Kızılaslan H. (2014). TR83 Bölgesinde Süt ve Süt Ürünleri Tüketiminde Tüketici Davranışlarını Etkileyen Faktörler ve Talebin Belirlenmesi, TEPGE, NO: 274.

Kotler, P., \& Armstrong, G. (2004). Principals of Marketing, New Jersey: Pearson Education INC.

Kurajdova, K., \& Petrovicova, J.T. (2015). Literatüre Review on Factors Influencing Milk Purchase Behaviour, International Review of Management and Marketing, 5(1), 9-25.

Rugimbana R (2007). Generation Y: How cultural values can be used to predict their choiceo of electronic financial services, Journal of Financial Services Marketing, 11, 301313.
(70\%) use supermarkets. Except for the supermarket preference, the consumers are also using the dairies. On the other hand, the use of local markets and neighborhood markets is very low. Other than supermarkets, purchases are also made from beans and the use of the internet is not the issue. The use of the internet for the purchase of dairy products is not available.

\section{Acknowlegment}

This research is derived from the individual research project FBA-2017-8251, supported by the Scientific Research Projects Unit of the University of Cukurova.

Onurlubaş, E., \& Çakırlar, H. (2016). Tüketicilerin Süt ve Süt Ürünleri Tüketimini Etkileyen Faktörlerin Belirlenmesi Üzerine Bir Araştırma, Çankırı Karatekin Üniversitesi Sosyal Bilimler Enstitüsü Dergisi, 7(1), 217-242.

Şeker, İ., Şeker, P., Şahin, M., Özen, V.S., Akdeniz, A., Erkmen, O., Kışlalığlu, İ., Sargın, G., \& Doğu, G.B. (2012). Elâzığ İli Merkez İlçede Tüketiciler Süt Tüketim Alışkanlıklar ve $\mathrm{Bu}$ Alışkanlıkları Etkileyen Faktörlerin Belirlenmesi, F.Ü. Elâzı̆̆ İli Merkez Sağlık Bilimler Vet. Derg, 26(3), 131-143.

Terin, M. (2014). Dünya Süt ve Süt Ürünleri Üretim, Tüketim, Fiyat ve Ticaretindeki Gelişmeler, Iğdır Üni. Fen Bilimleri Enst. Der, 4(3), 53-63.

Terin, M., Bilgiç, A., Güler, İ.O., \& Yavuz, F. (2015). Türkiye'de Süt Ürünleri Tüketim Harcamaları Etki Eden Faktörlerin Analizi: Çoklu Heckman Örneklem Seçicilik Sistem Yaklaşımı, Tarım Bilimler Dergisi, 21, 500-515. 